\title{
EFFECT ON PROMOTION, MOTIVATION, LIFESTYLE, AND PERSONAL SELLING OF INTEREST USING CREDIT CARDS ${ }^{1}$
}

\author{
Sunanda, Dr. Mirza, ST.MM \\ Postgraduate Masters in Management, \\ Mercubuana University, UMB, Jakarta, Indonesia
}

DOI: $10.37648 /$ ijrst.v10i02.001

Received: 15 ${ }^{\text {th }}$ February, 2020; Accepted:20 th March, 2020; Published: 08 ${ }^{\text {th }}$ April, 2020

\begin{abstract}
Credit cards are a great demand by urban communities, especially in the DKI Jakarta area. Because credit cards have considerable benefits in terms of prospective debtors. The problem of this study originates from Bank Mega market share, which is in the sixth position, the number of Bank Mega credit card users from 2012 to 2018 which is volatile and does not achieve the target of acquiring new customers for credit card users in the January to October 2019 period. This research is to find outinfluence factors of someone's interest to use a credit card. The data collection process carried out by distributing questionnaires to 240 credit card users outside of Bank Mega in Greater Jakarta. The questionnaire results analyzed and processed using SPSS 25.0. The analysis results show that motivation variable has the greatest influence on interest in using a credit card, while the effect size is $33.7 \%$, followed by personal selling variables which have an influence on interest in using a credit card by $11.4 \%$, promotion variable has an influence on interest use a credit card of $10.1 \%$, but for lifestyle variables do not have a significant effect on interest in using a credit card because it only has an influence of $1.3 \%$.

Keywords: motivation, personal selling, interests, credit cards
\end{abstract}

\section{INTRODUCTION}

Based on data from liputan 6.com in 2018 about the great demand of credit cards by urban communities, especially in DKI Jakarta area. This is because credit cards have considerable benefits in terms of prospective borrowers, that are: (1) Practicality, which the prospective debtor does not need to carry large amounts of cash because it is dangerous, (2) Expenses condensation, where the prospective debtor will get many benefits in terms discount; (3) Payment by installment system, whereconsumers get convenience in terms of payment in installments (monthly, yearly) so that it is not too burdensome payment in large amounts for prospective borrowers; (4) Getting reward points, prospective debtors are more profitable with the acquisition of reward points for each purchase transaction, which in the end this point will be utilized again on the next transaction; (5) Reserve funds, meaning prospective debtors can more easily make large and sudden payments (Hospitals, Education, etc.).

${ }^{1}$ How to cite the article: Sunanda, Dr. Mirza, Effect on Promotion, Motivation, Lifestyle and Personal Selling of Interest Using Credit Cards, IJRST, AprJun 2020, Vol 10, Issue 2, 1-7, DOI: http://doi.org/10.37648/ijrst.v10i02.001 
(IJRST) 2020, Vol. No. 10, Issue No. II, Apr-Jun

The explanation above can be interpreted that the high demand for the use of credit cards for urban communities
e-ISSN: 2249-0604, p-ISSN: 2454-180X

so that it provides benefits for banks in terms of product innovation (Credit Card).

There are many players who have credit card products in banking, especially in DKI Jakarta. Based on data from Cermati.com in 2019, there are 5 biggest banks that have credit card products as shown in table 1.1 below.

Table 1.1 Credit card market share data

\begin{tabular}{|l|l|l|l|l|l|}
\hline No & Bank Name & Number ofCards & $\begin{array}{l}\text { Percentage } \\
\text { Number of Users }\end{array}$ & Interest Interest Rate & Annual \\
\hline 1 & Bank BCA & $\mathbf{3 . 7}$ Million & $\mathbf{2 1 . 4 2 \%}$ & $\mathbf{2 . 7 5 \%}$ & Rp 125,000 \\
\hline 2 & CIMB Niaga & 2.6 Million & $15.05 \%$ & $2.95 \%$ & Rp 250,000 \\
\hline 3 & Bank Mandiri & 2.0 Million & $11.58 \%$ & $2.95 \%$ & Rp 180,000 \\
\hline 4 & Bank BRI & 1.9 Million & $11.00 \%$ & $2.95 \%$ & Rp 250,000 \\
\hline 5 & Bank BNI & 1.85 Million & $10.71 \%$ & $2,95 \%$ & $\operatorname{Rp~240,000}$ \\
\hline 6 & Bank Mega & 1.75 Million & $10.13 \%$ & $2.95 \%$ & $\operatorname{Rp~400,000}$ \\
\hline
\end{tabular}

Source: Annual Report in several Banks (2018)

Based on table 1.1 above, there are two biggest player banks in terms of credit card users, namely Bank BCA amounting to 21.42\%; Bank CIMB Niaga was 15.05\%, while Bank Mega was in sixth position, 10.13\%. This means that Bank Mega is not the main target for prospective borrowers in choosing credit card collection. This is reinforced by the Bank Mega credit card interest rate $2.95 \%$ higher than Bank BCA by $2.75 \%$, in addition to the amount of contributions that must be paid by prospective credit card debtors for Bank Mega Rp 400,000 higher.

\section{NUMBER OF BANK MEGA CREDIT CARD USERS 2012-2018}

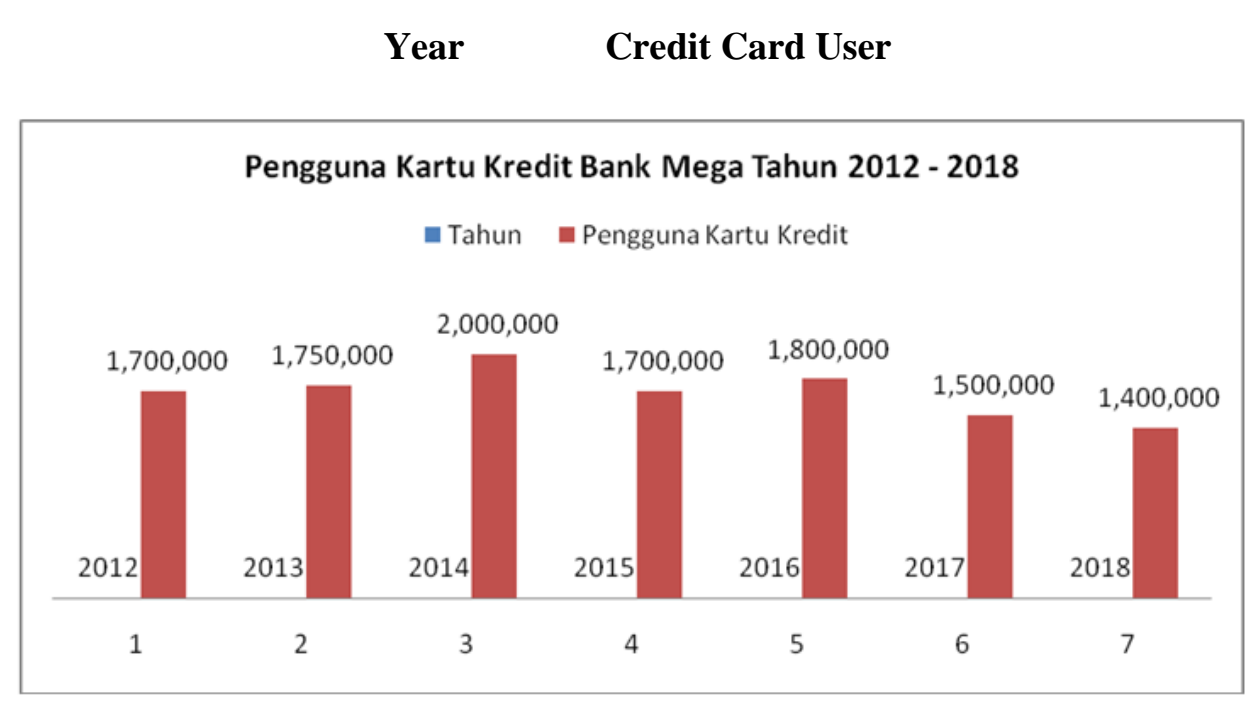

Figure 1.1 Total number of Bank Mega credit card users in DKI 2012-2018 
Based on figure 1.1 above, there was a fluctuation in total number of Bank Mega credit card users. In 2016 until 2018 there was a decrease on total number of Bank Mega credit card users in DKI Jakarta. In addition, based on monthly reports from Mega Bank's internal management as seen in table 1.2 below, there is a gap between target and realization of Bank Mega new credit card users number, both in the entire DKI area and at the Bank Mega headquarters. In 2019, the realization of newcredit card users achievement number.

Bank Mega(new users) has not yet reached the target set by Bank Mega management, both in the entire DKI area and for the central office itself. It can be concluded that prospective bank credit card debtors in Mega have not been interested in using Bank Mega credit cards, so that researchers and Bank Mega management need to study more closely about the factors that can influence prospective borrowers to propose the use of Mega bank credit cards.

\begin{tabular}{|l|l|l|l|l|}
\hline \multicolumn{3}{|l|}{ Table 1.2 Acquisition of Bank Mega New Credit Card Users from January to } \\
September 2019 & $\begin{array}{l}\text { Target Acquisition } \\
\text { Number Card Users } \\
\text { New In DKI Jakarta }\end{array}$ & $\begin{array}{l}\text { Realization Users } \\
\text { New Card Credit in } \\
\text { DKI Jakarta }\end{array}$ & $\begin{array}{l}\text { Acquisition of New } \\
\text { Credit Card Users in } \\
\text { head quarters office }\end{array}$ & $\begin{array}{l}\text { Realization of New } \\
\text { Credit Card Users in } \\
\text { head quarters office }\end{array}$ \\
\hline January & 11,120 & 6,521 & $\mathbf{4 2 0}$ & $\mathbf{1 7 8}$ \\
\hline February & 11958 & 5655 & $\mathbf{5 4 0}$ & $\mathbf{1 8 0}$ \\
\hline March & 12183 & 5,641 & $\mathbf{6 0 0}$ & $\mathbf{1 7 0}$ \\
\hline April & 13462 & 6294 & $\mathbf{7 0 0}$ & $\mathbf{1 4 8}$ \\
\hline May & 10,975 & 7015 & $\mathbf{7 0 0}$ & $\mathbf{1 1 2}$ \\
\hline June & 8779 & 2421 & $\mathbf{4 0 0}$ & $\mathbf{1 5}$ \\
\hline July & 11117 & 6894 & $\mathbf{5 0 0}$ & $\mathbf{9 2}$ \\
\hline August & 10655 & 5890 & $\mathbf{5 0 0}$ & $\mathbf{5 8}$ \\
\hline September & 11636 & 3896 & $\mathbf{5 0 0}$ & $\mathbf{1 7 0}$ \\
\hline
\end{tabular}

Source; Bank Mega internal management data in 2019

However, based on interviews results with debtors of other Bank credit card users about 30 respondents as shown in Figure 1.2 below where there are 4 main factors that cause respondents to apply for Bank Mega credit cards, namely (1) Many programs a discount of 23 respondents, (2) for emergency needs (motivation to use credit) of 19 respondents, (3) for online transactions (lifestyle) of 17 respondents, (4) sales team (personal selling) of 12 respondents. 


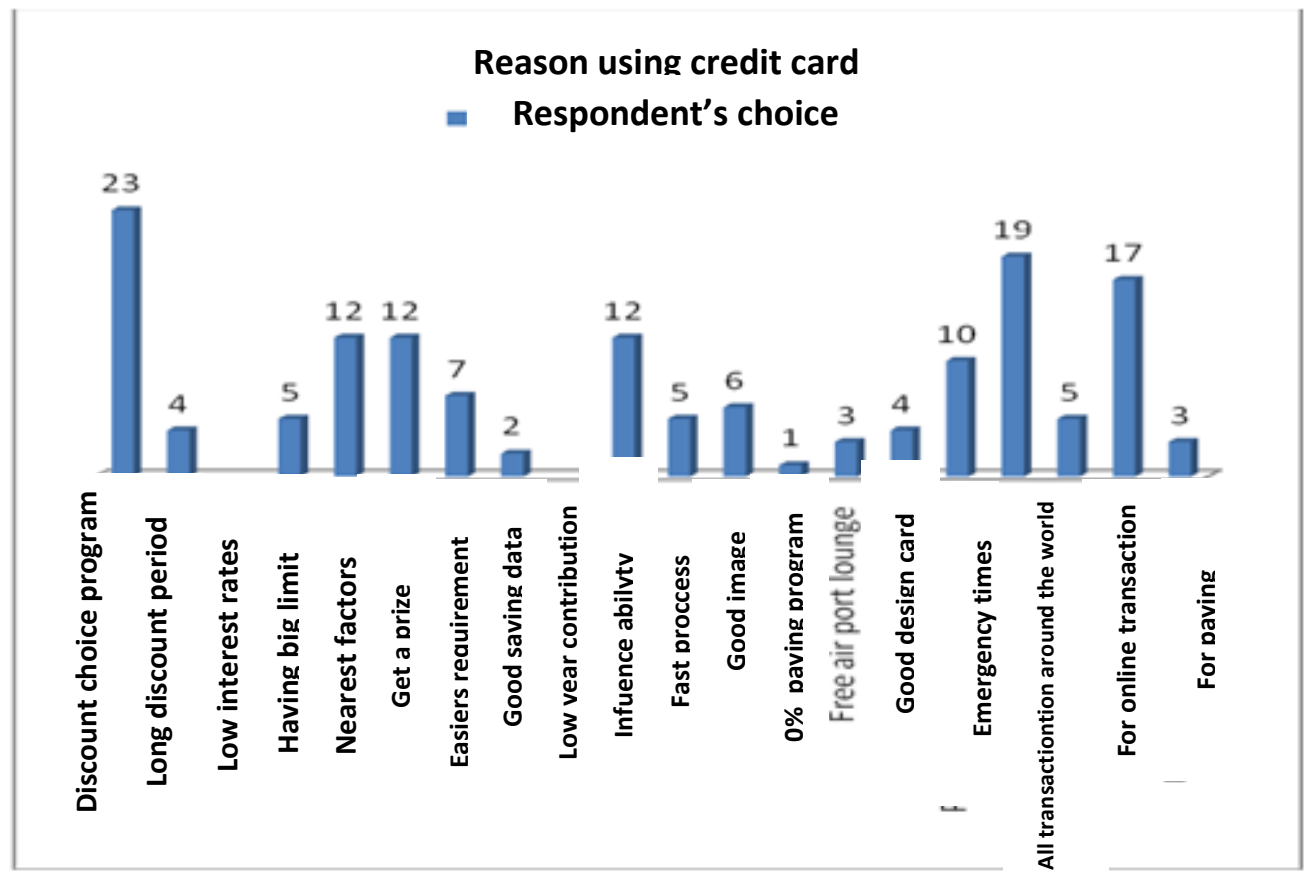

Figure 1.2 Focus Group Discussion Results

Source: Focus Group Discussion and Questionnaire Survey

The purpose of this study is to identify the interests of prospective borrowers using Bank Mega credit cards, analyze the influence factorsas interests of prospective borrowers using Bank Mega credit cards, andprovide alternative strategic recommendations which can be used to increase the interest of prospective borrowers to use Bank Mega credit cards.

\section{RESEARCH METHODS}

Sampling is done bynon-probabilistic sampling methods called purposive sampling. The specific criteria of the respondent, the objectives and information to be explored in the study, including the domicile or residence of the respondent in the Greater Jakarta area, customers who already have a credit card outside of the Bank Mega credit card. The number of population in this study is unknown, so if the population is unknown, according to Hair et al in Prawira (2010: 46) recommends a minimum sample size of 5 times the number of question items contained in the questionnaire. Total questions in this study were 48 questions, so the minimum sample size of this study was $48 \times 5=240$ So the number of samples taken in this study were 240 respondents. The analytical method used in this study is descriptive statistical analysis with multiple linear regression using thetool SPSS. The term multiple linear regression can also be referred to as multiple regression (Riadi, 2016).

The multiple linear regression model is explained with the following equation:

$\mathrm{Y}=\alpha+\beta 1 \mathrm{X} 1+\beta 2 \mathrm{X} 2+\beta \mathrm{nXn}+\mathrm{e}$

Description:

$\mathrm{Y}=$ Dependent variable.

$\mathrm{X}=$ free variable.

$\alpha=$ Constant.

$\beta=$ Slope or estimated coefficient.

Based on the results of the explanation above, so the research model can be seen in the image below. 


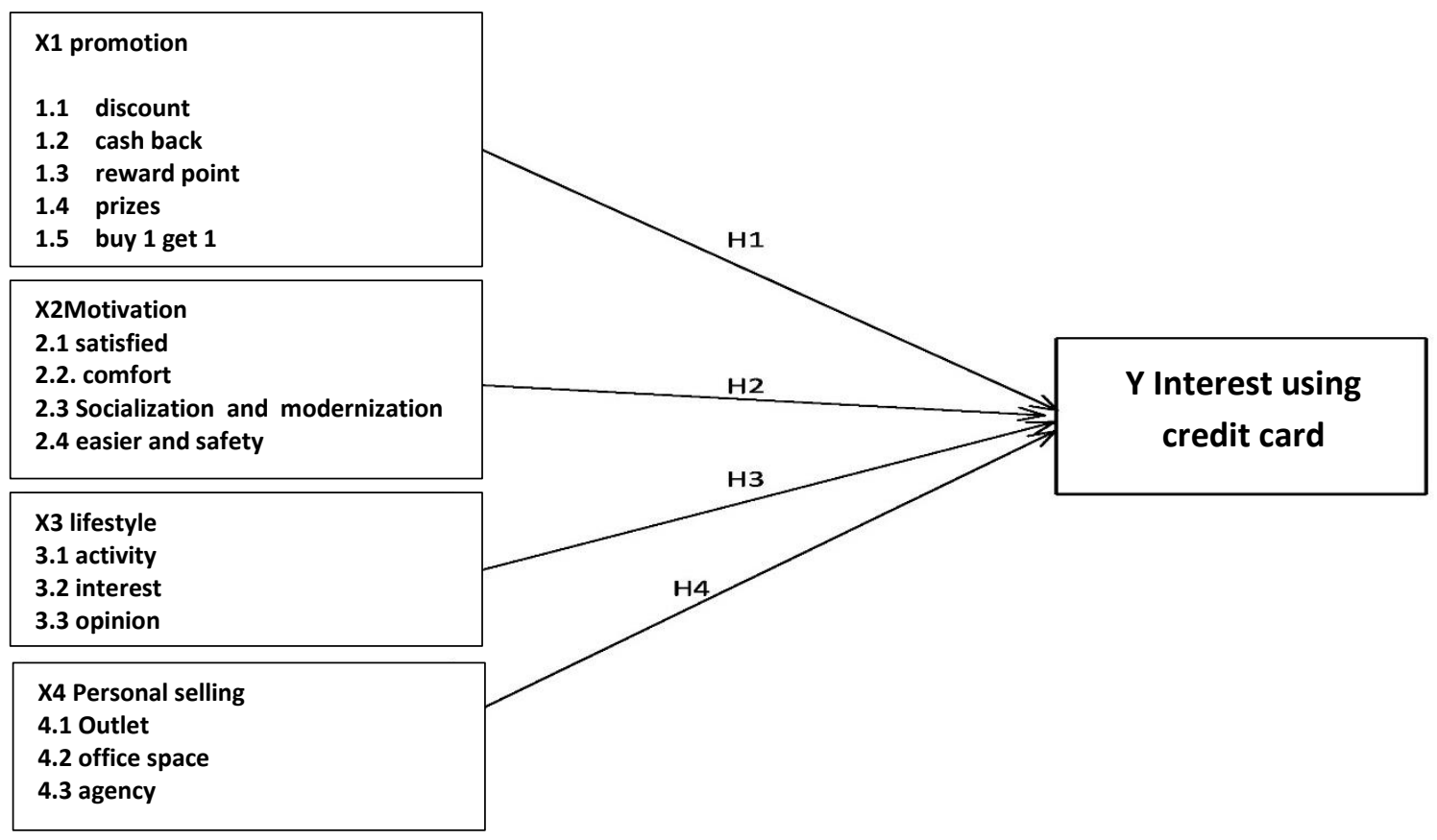

Figure 1.1 Research Model

Source: Processed

\section{RESULTS}

\section{Respondent Characteristics}

Respondent characteristics show that the majority of credit card users are women (60\%), with the majority age range above 20 years by 79\%, having the type of work as private employees and PNS / BUMN (62\%), and status is married (55\%). This means that users or prospective credit card users are adult women who have an income above 5 million rupiah. And the use of credit cards is dominated byworked adult women where other types of bank credit cards are often used are BCA credit cards (35\%) and Bank Mandiri credit cards (25\%). The majority of the use of credit cards is done once a month (14\%), and the use of these credit cards is for online shopping payments and overseas shopping transaction payments (55\%), with an average number of users worth under 5 million per month (72.8\%).

\section{Individual Significance Test (T Statistical Test) Significance}

Interpret test to independent variable, has an influence or not on the dependent variable. In addition, this significance test knows the effect of each independent variable on the dependent variable. Based on table 4.11 below where there is one variable that has noinfluence on the interest in using a credit card that is the lifestyle variable $(0.812)$ because its value is greater than alpha (0.05). While other variables have an influence on interest in using credit cards, namely Promotion (0.040), Motivation (0.00) and personal selling (0.045) because the value is smaller than alpha (0.05). 
Table 4.11 Individual Test Results (Statistical Test T)

\begin{tabular}{|c|c|c|c|c|c|c|}
\hline \multirow{2}{*}{\multicolumn{2}{|c|}{ Model }} & \multicolumn{2}{|c|}{ Unstandardized Coefficients } & \multirow{2}{*}{$\begin{array}{l}\text { Standardized Coefficients } \\
\text { Beta }\end{array}$} & \multirow[b]{2}{*}{$\mathrm{t}$} & \multirow[b]{2}{*}{ Sig. } \\
\hline & & B & Std. Error & & & \\
\hline \multirow[t]{5}{*}{1} & (Constant) & 4,052 & 2,107 & & 1923 & .056 \\
\hline & sale & .102 & .050 & .128 & 2.060 & .040 \\
\hline & motivation & .337 & .042 & .479 & 7.942 & .000 \\
\hline & Lifestyle & .013 & .053 & .015 & .238 & .812 \\
\hline & personalselling & .114 & .057 & .121 & 2.013 & .045 \\
\hline
\end{tabular}

Source: Data Olah ( 2019)

Based on Table 4.11 above, it is known that the resulting regression equation is $\mathrm{Y}=4.052+0.102 \mathrm{X}_{1}+0.337 \mathrm{X}_{2}+$ $0.013 \mathrm{X}_{3}+0.114 \mathrm{X}_{4}$ which can be interpreted as follows:

1. Constant of $\mathrm{a}=4.052$. If promotion $\left(\mathrm{X}_{1}\right)$, motivation $\left(\mathrm{X}_{2}\right)$, lifestyle $\left(\mathrm{X}_{3}\right)$ and personal selling $\left(\mathrm{X}_{4}\right)$ are considered zero (no), then the interest in using a Mega Bank (Y) credit card is worth 4.052 units.

2. Based on the terms of acceptance of the hypothesis that is if $\mathrm{t}$ arithmetic $>\mathrm{t}$ table orvalue sig $\alpha<\alpha 0.05$, so that all hypotheses are accepted. The positive $\beta$ coefficient value means that if the value of $X$ goes up, the value of $\mathrm{Y}$ will also go up, conversely the value of the negative $\beta$ coefficient means that if the value of $\mathrm{X}$ goes up, the value of $\mathrm{Y}$ will go down.

a. The promotion variable $\left(\mathrm{X}_{1}\right)$ has $\mathrm{t}$ arithmetic $=2.060>\mathrm{t}$ table $=1.645$ and $\operatorname{sig} \mathrm{t}=0.04<\alpha=$ 0.05 , the effect of the variable $X_{1}$ on the variable $\mathrm{Y}$ is significant. The coefficient value $\beta 1$ is positive $=0.050$ which indicates that the direction of the relationship between promotion $\left(\mathrm{X}_{1}\right)$ with interest in using a credit card is positive. If motivation $\left(\mathrm{X}_{2}\right)$, lifestyle $\left(\mathrm{X}_{3}\right)$, and personal selling $\left(\mathrm{X}_{4}\right)$ are considered zero (no or not done) then the promotion variable $\left(\mathrm{X}_{1}\right)$ will affect the interest in using a credit card (Y) of $0.102(10,2 \%)$

b. Motivational variable $\left(\mathrm{X}_{2}\right)$, has $\mathrm{t}$ arithmetic $=$ 7.942 $>\mathrm{t}$ table $=1.645$ and sig $\mathrm{t}=0.000<\alpha=$ 0.05 , the influence of variable $\mathrm{X}_{2}$ on variable $\mathrm{Y}$ is significant. Coefficient of positive $\beta 2=$ 0,337 yang show that arahhubungan between motivation $\left(\mathrm{X}_{2}\right)$ with an interest in using a credit card is positive. If promotion $\left(\mathrm{X}_{1}\right)$, lifestyle $\left(\mathrm{X}_{3}\right)$ and personal selling $\left(\mathrm{X}_{4}\right)$ are considered zero (none or none), then motivationvariable $\left(\mathrm{X}_{2}\right)$, will affect interest in using a credit card (Y) by 0.337 times $(33.7 \%)$.

c. Lifestyle $\left(\mathrm{X}_{3}\right)$ has $\mathrm{t}$ count $=0.238<$ table $=$ 1.645 and sigt $=0.812>\alpha=0.05$, the effect of the $\mathrm{X}_{3}$ variable on the $\mathrm{Y}$ variable is not significant. The coefficient value $\beta 3$ is positive $=0.013$ which indicates that the direction of the relationship between lifestyle $\left(\mathrm{X}_{3}\right)$ with interest in using a credit card is positive. If promotions $\left(\mathrm{X}_{1}\right)$, motivation $\left(\mathrm{X}_{2}\right)$, personal selling $\left(\mathrm{X}_{4}\right)$ are considered zero (no or not done), then lifestyle variables $\left(\mathrm{X}_{3}\right)$ will affect interest in using a credit card (Y) by 0.013 times $(1,3 \%)$.

d. Personal selling variable $\left(\mathrm{X}_{4}\right)$ has $\mathrm{t}$ count $=$ 2.013> $\mathrm{t}$ table $=1.645$ and sigt $=0.045<\alpha=$ 0.05 , the effect of variable $\mathrm{X}_{4}$ on variable $\mathrm{Y}$ is significant. Coefficient of positive $\beta 4=$ 0,114 yang show that arahhubungan between personal selling $\left(\mathrm{X}_{4}\right)$ with an interest in using a credit card is positive. If promotion $\left(\mathrm{X}_{1}\right)$, motivation $\left(\mathrm{X}_{2}\right)$, and lifestyle $\left(\mathrm{X}_{3}\right)$ are considered zero (no or not done), then personal selling variable $\left(\mathrm{X}_{4}\right)$ will affect interest in using a credit card (Y) by 0.114 times ( $11.4 \%)$. 
(IJRST) 2020, Vol. No. 10, Issue No. II, Apr-Jun

\section{CONCLUSIONS AND SUGGESTIONS}

\section{Conclusions}

1. Promotion has a significant and positive effect on interest in using Bank Mega credit cards. The effect is $10.1 \%$. This means that if management aggressively promotes, it can increase the interest of potential credit card users.

2. Motivation has a significant and positive effect on the interest in using Bank Mega credit cards. The influence is $33.7 \%$. This means that if management socializes the benefits of using a credit card for prospective borrowers, the impact will be on increasing the motivation of prospective borrowers to use credit cards.

3. Lifestyle does not significantly and positively influence interest in using Bank Mega credit cards. Because it only has a very small influence and the majority of respondents perceive that the Mega Bank credit card has not been able to increase the prestige and prestige for prospective borrowers.

4. Personal Selling has a significant and positive effect on interest in using Bank Mega credit cards. The effect is $11.4 \%$. This means that if management conducts training for credit card salespeople in the form of intensive knowledge and communication skills and communication skills training with
e-ISSN: 2249-0604, p-ISSN: 2454-180X

prospective borrowers, it will have an impact on the behavior and knowledge changes of Bank Mega credit card salespeople which in turn can influence prospective borrowers to use credit cards.

5. There are influences on promotion, motivation, lifestyle, personal selling together and the influence on interest in using a credit card. The variables that have the most influence are motivation and personal selling.

\section{Suggestions}

This research focuses on interest in using Bank Mega credit cards in the Jabodetabek area where it is a region with higher and more intense banking service intensity, while outside Jabodetabek it also has a high intensity of credit card usage. So for further researchers who are interested in discussing the interest in using a Mega Bank credit card can take the study population outside Jabodetabek.

Based on the results of the model summary table where the Rsquare value of this study is 0.368 . This means that there are still other variables that affect interest in using a credit card besides the variables examined in this study. So that the next researcher should examine other factors out of the variables in this study, namely attitude, demographic conditions, economic, political, social and cultural conditions and the influence of family and friends

\section{BIBLIOGRAPHY}

[1] Bank Indonesia. (2012). Bank Indonesia Regulation Number: 14/2 / PBI / 2012 concerning. Amendments to PBI Number: 11/11 / PBI / 2009 concerningInstrument Activities PaymentUsing the Card

[2] Peter, Donnelly. 2011. Marketing Management: Knowledge and Skills, 10th Edition (Custom McGraw-Hill Create Customized Edition)

[3] Riadi, Edi. (2016). Statistics Research Analysis Manual and IBM SPSS). Issue 1. Yogyakarta: ANDI.

[4] Setiadi, Nugroho J. 2003. Consumer Behavior: Concepts and Implications for Marketing Strategy and Research. Kencana. Jakarta. 436 pp.

[5] Sugiarto, Eko. (2017). Develop Qualitative Research Proposals: Thesis and Thesis. Yogyakarta: Media Asylum 